\title{
Determination of Caffeine and Taurine Contents in Energy Drinks by HPLC-UV
}

\section{KRISHNA PRASAD RAI ${ }^{1 *}$, HASTA BAHADUR RAI ${ }^{2}$, SANTOSH DAHAL ${ }^{1}$, SAROJ CHAUDHARY ${ }^{1}$ and SURAJ SHRESTHA ${ }^{1}$}

${ }^{1}$ Central Food Lab, DFTQC, Babarmahal, Kathmandu, Nepal

${ }^{2}$ Quality Control Division, DFTQC, Babarmahal, Kathmandu, Nepal

Energy drinks are non-alcoholic beverage intended to enhance the psycho-physiological responses in human, which is especially popular among young generation in Nepal. It is normally high caffeinated drink added with other ingredients such as carbohydrates, amino acids, B-group of vitamins etc. In this study, 10 brands of energy drink available in Nepalese markets were taken then analyzed for quantitative determination of Caffeine and Taurine by HPLC-UV method. From the result obtained, $p H$ and TSS values of energy drinks were found in the range of 2.96-3.81 and 6.64-18.21 respectively. Likewise, the Caffeine and Taurine content in same samples were found in the range of not detected (ND) to $35.78 \mathrm{mg} / 100$ $\mathrm{ml}$ and $\mathrm{ND}$ to $387.5 \mathrm{mg} / 100 \mathrm{ml}$ respectively. Only the 6 samples out of 10 were confirmed caffeine content as per claimed in label, while only 3 samples were confirmed for Taurine content as per label claimed. Based on this pilot study, the majority of samples did not meet the label claims in term of Caffeine and Taurine, which apparently indicated the misbranding of such drinks. Since, there is no any regulation for such energy drinks in Nepal, it seems to be a great challenge for regulation of their safety and misbranding.

Keywords: Energy drinks, HPLC-UV, Label, Caffeine, Taurine

\section{Introduction}

Energy drinks are non-alcoholic functional beverage intended to enhance the psycho-physiological responses in human. These may include caffeine, D-glucuronolactone, B vitamins, taurine, carbohydrate, and herbal extracts such as guarana, ginseng etc. Energy drinks typically contain high levels of caffeine, sugar, and other ingredients viz. taurine, B-complex vitamins, ginseng, and guarana seed extract (Smith et al., 2000; Usman and Jawaid, 2012; Duncan \& Hankey, 2013; Saritas et al., 2014). The importance of taurine as a dietary supplement was first realized by a Japanese in 1949 (Stapleton et al., 1997). According to CAC (2001), energy drinks could also be classified within the Codex category of Special Purpose Foods because they are designed to perform a specific function.

Energy drink was first introduced in 1960s by Taisho Pharmaceuticals (Japan) as a medicinal tonic drink. In 1987, Dietrich Mateschitz, an Austrian, added caffeine and sugar and named this drink as Red Bull, after the taurine amino acid (Reissig et al., 2009). Since its inception, the energy drink market has grown exponentially, with nearly 500 new brands launched worldwide in 2006 (Johnson, 2006).Energy drinks are very popular among young individuals such as college students, athletes, and active individuals between the ages of 21 and 35 years (Dikici et al., 2013). In Nepal a similar findings has been reported, where the respondents $(n=151)$ of age 20 to 30 years consuming energy drinks regularly was $52 \%$ and only $2 \%$ of the respondents were of age above 60 . Similarly, $66 \%$ were male and $34 \%$ female who consumed such energy drinks regularly (Humagain et al., (2013). Aluqmany et al., (2013) also reported the increase of consumption of such energy drinks among secondary school level female students in Saudi Arabia.

However, excessive consumption of such energy drinks has been associated with epileptic seizure, ischemic stroke or transient ischemic attack (Saritas et al., 2014). In context of non-existence of regulation on energy drinks labelling in Nepal, and limited studies on these drinks, this study aims to set up the HPLC method for analysis of Caffeine and Taurine, which are main active ingredients of energy drinks.

Caffeine and Taurine (an amino acid) are major vital ingredients in most of energy drinks. Caffeine is a natural compound present in coffee beans and tea leaves; however, some other sources are cocoa beans, kola nut, yerba mate,

\footnotetext{
*Corresponding author, E-mail: raikrishna1@gmail.com 
guarana berries and yaupon holly etc. Caffeine has claimed that it may helps to increase alertness mainly targeting to adult population (EFSA, 2014). Daily intake upto 400mg<smiles>NCCS(=O)(=O)O</smiles>

per day (about $5.7 \mathrm{mg} / \mathrm{kg}$ bw per day) consumed do not raise safety concerns for healthy adults in the general population, except pregnant women (EFSA, 2013).<smiles>Cn1c(=O)c2c(ncn2C)n(C)c1=O</smiles>

Figure 1. Taurine \& Caffeine

Taurine or 2-amino ethane sulfonic acid is a metabolic product of sulphur containing amino acid mainly biosynthesized from cysteine in liver and found up to $0.1 \%$ of total human body weight. It has many fundamental biological roles viz. conjugation of bile acids, antioxidation, osmoregulation, membrane function and development and function of skeletal muscle and central nervous system (SCF, 1999; Huxtable, 1992). The NOAEL of Taurine is $1000 \mathrm{mg} / \mathrm{kg}$ bw/day has been set on the basis of 90 day rat study (Rotstein, 2013).

Since there is no any mandatory standard formulated for energy drinks and for other vital ingredients such as caffeine and taurine. There are some cases have been reported that the excessive consumption of such energy drinks have been associated with cause epileptic seizure, ischemic stroke or transient ischemic attack (Saritas et al., 2014). In the context of having no regulation exists in Nepal and very few studies have been accomplished in previous study, this study mainly aims to set up the HPLC method for analysis of caffeine and taurine, which are main active ingredients of energy drinks.

\section{Materials and Methods}

\section{Preparation of carbonate buffer}

A $10 \mathrm{ml} \mathrm{mM}$ of pH 9 carbonate buffer solution was made for use in the derivatization reaction by dissolving $0.2081 \mathrm{~g}$ of $\mathrm{NaHCO}_{3}$ (AR grade) and $0.0138 \mathrm{~g}$ of $\mathrm{Na}_{2} \mathrm{CO}_{3}$ (AR grade) in $250 \mathrm{ml}$ distilled water. Then adding hydrochloric acid dropwise until a $\mathrm{pH}$ of 9 was reached. The remaining solution was then diluted with distilled water to final volume of 250 ml (McConn, 2012).

\section{Preparation of Phosphate buffer for HPLC mobile phase}

A $10 \mathrm{mM}$, pH 6 phosphate buffer solution was made for the HPLC mobile phase by dissolving $1.298 \mathrm{~g}$ of $\mathrm{NaH}_{2} \mathrm{PO}_{4}$ (AR grade) and $0.158 \mathrm{~g}$ of $\mathrm{Na}_{2} \mathrm{HPO}_{4} .7 \mathrm{H}_{2} \mathrm{O}$ (AR grade) in distilled water to a final volume of $2 \mathrm{~L}, \mathrm{pH}$ adjusted by $\mathrm{NaOH}$ then filtered and degassed in sonicator before use in HPLC (McConn, 2012).

\section{Preparation of Standards}

Caffeine standards: Altogether 6 standards having different concentration of 2, 4, 10, 15, 25 and 50 ppm were prepared from 100 ppm stock solution of Caffeine standard (Sigma-Aldrich) in HPLC grade water. All the standards were degasses by sonication before filling in HPLC vials for injection. From the standard curve, the $\mathrm{r}^{2}$-value for Caffeine was 0.999 and for Taurine is 0.993 .

Taurine standards: Altogether 5 different standards of Taurine having concentration of 10, 20,

30, 40 and $50 \mathrm{ppm}$ were prepared from 100ppm stock solution of standard Taurine (Sigma-Aldrich) with HPLC water according to the method described by McConn, (2012).

\section{Sample collection}

Altogether 10 different brands of energy drinks (all in can) were mainly collected from local market of Kathmandu, Nepal. All the samples were kept inside refrigeration temperature until all the analysis has been completed.

\section{Sample preparation}

Twenty five $\mathrm{ml}$ of the energy drink from each sample were taken into a $150 \mathrm{ml}$ Erlemeyer flask and degassed by sonication for $10 \mathrm{~min}$. Dilutions of 1:200 was done for all samples with distilled water (McConn, 2012).

\section{Derivatization reaction}

The derivatization procedure was the same for standards and all samples. $1 \mathrm{ml}$ of sample, $2 \mathrm{ml}$ of the carbonate buffer, $0.1 \mathrm{ml}$ of 2, 4-dinitrofluorobenzene (DNFB) AR grade were mixed by shaking for $30 \mathrm{sec}$. The mixture was placed in a $40^{\circ} \mathrm{C}$ water bath for $15 \mathrm{~min}$. At the end of the $15 \mathrm{~min}, 6.5 \mathrm{ml}$ 
of the phosphate buffer was added to the mixture (McConn, 2012)

\section{HPLC conditions for Caffeine}

- $\quad$ HPLC model 1514 (Simadzu Corporation)

- Column: Zorbax Eclipse Plus 18 C Column, pore size $5 \mu$, internal diameter $4.6 \mathrm{~nm}$ and length $150 \mathrm{~mm}$.

- $\quad$ Flow rate: $1 \mathrm{ml} / \mathrm{min}$ (constant),

- Column temperature: $40^{\circ} \mathrm{C}$

- UV detector set at $275 \mathrm{~nm}$

- Mobile phase: HPLC grade Water and Methanol (60:40)

- $\quad$ Sample injection volume: $10 \mu \mathrm{l}$

\section{HPLC condition for Taurine}

Binary gradient with time programing in total flow as well as in pump B (Acetonitrile) was applied. The sample injection volume was $10 \mu \mathrm{l}$ and the detection wavelength was $360 \mathrm{~nm}$. Rest of conditions were as same as applied in determination of caffeine.

pH measurement: $\mathrm{pH}$ of each energy drinks sample were conducted by using Mettler Toledo $\mathrm{pH}$ meter after two points calibrations with standard buffers 4 and $9 \mathrm{pH}$ (SigmaAldrich).

TSS measurement: TSS was measured by calibrated Automatic digital Refractometer (Rudolph J257, USA) at $20^{\circ} \mathrm{C}$.

Table 1. Label observation of 10 different brands of Energy drinks available in Nepalese markets

\section{Resultw and Discussion}

Label study- 10 different samples of energy drinks produced from 6 different countries were studied (Table 1). Majority of samples were found from Thailand. All the samples claimed no protein and fat except sample ED-9, which claimed trace amount of protein. Similarly, two samples claimed no caffeine and taurine. Most of brands contained Vitamin B3, B5, B6 and B12, though they were lacking in Vitamin C and sodium content. All the energy drinks were packed in 250 $\mathrm{ml}$ net capacity aluminum cans containing warning message 'Do not mix with alcohol'. The excessive consumption of such energy drinks with alcohol had shown ischemic stroke and epileptic seizure in empty stomach (Dikici et al., 2013, Saritas et al., 2014). The label of sample ED-7 claimed no Taurine but its content was quantified as $3332.1 \mathrm{mg} / \mathrm{L}$, which is contradictory with claim. A recent survey report of Humagain et al., (2013), interestingly showed that 54\% of the respondents assumed that energy drinks are compatible with alcohol. This is quite concerning situation about the awareness of energy drinks consumption in Nepal.

From the comparative analysis of results and label claim for energy drinks samples only 6 samples out of 10 matched their claims, it seems to be false claim in term of vital components in energy drinks label. Therefore, majority of energy drinks samples did not meet the claims in terms of Caffeine and Taurine contents. Humagain et al., (2013) has also reported the similar results in their study of energy drinks found in Nepal.

\begin{tabular}{|c|c|c|c|c|c|c|c|c|c|c|c|c|c|c|c|c|}
\hline \multirow[b]{2}{*}{$\begin{array}{l}\text { Sample } \\
\text { ID }\end{array}$} & \multicolumn{15}{|c|}{ Composition per $100 \mathrm{ml}$ drinks } & \multirow[b]{2}{*}{$\begin{array}{l}\text { Manufacturing } \\
\text { country }\end{array}$} \\
\hline & $\begin{array}{l}\text { Calorie } \\
\text { (Kcal) }\end{array}$ & $\begin{array}{l}\text { Carbohydrate } \\
\text { (g) }\end{array}$ & $\begin{array}{l}\text { Sugar } \\
(\mathrm{g})\end{array}$ & $\begin{array}{l}\text { Protein } \\
(\mathrm{g})\end{array}$ & Fat $(g)$ & $\begin{array}{l}\text { Caffiene } \\
(\mathrm{mg})\end{array}$ & $\begin{array}{l}\text { Taurine } \\
(\mathrm{mg})\end{array}$ & $\begin{array}{l}\text { Sodium } \\
(\mathrm{mg})\end{array}$ & $\begin{array}{l}\text { Vit-B2 } \\
(\mathrm{mg})\end{array}$ & $\begin{array}{l}\text { Vit-B3 } \\
\text { (mg) }\end{array}$ & $\begin{array}{l}\text { Vit-B5 } \\
(\mathrm{mg})\end{array}$ & $\begin{array}{l}\text { Vit-B6 } \\
(\mathrm{mg})\end{array}$ & $\begin{array}{l}\text { Vit-B12 } \\
(\mu \mathrm{g})\end{array}$ & $\begin{array}{l}\text { Vit-C } \\
(\mathrm{mg})\end{array}$ & Other ingredients & \\
\hline ED-1 & 72 & 18 & 15.6 & N/A & N/A & 32 & 400 & N/A & N/A & 8 & 2 & 1.2 & 1.6 & N/A & $\begin{array}{l}\text { Choline, IS, Color, } \\
\text { Flavor }\end{array}$ & Thailand \\
\hline ED-2 & 56 & N/A & 13.75 & N/A & N/A & 29 & N/A & N/A & N/A & 8 & 2 & 1.2 & 1.6 & N/A & Flavor, color & Thailand \\
\hline ED-3 & 44 & 11.2 & 3 & N/A & N/A & N/A & 200 & N/A & N/A & 1.54 & 3 & N/A & N/A & N/A & $\begin{array}{l}\text { Color, TC, IS, CA, } \\
\text { SY }\end{array}$ & Thailand \\
\hline ED-4 & 44 & 10 & 10 & N/A & N/A & 30 & 400 & $\operatorname{Tr}$ & N/A & 6.5 & 2 & 0.56 & 0.5 & $\mathrm{~N} / \mathrm{A}$ & SC, Color, IS, SB & UK \\
\hline ED-5 & 72 & 18 & 15.6 & N/A & N/A & 32 & 400 & N/A & N/A & 8 & 2 & 1.2 & 1.6 & N/A & $\begin{array}{l}\text { Choline, IS, Color, } \\
\text { Flavor }\end{array}$ & Thailand \\
\hline ED-6 & 48 & 12 & 12 & N/A & N/A & 20 & 400 & 28 & 1 & 10 & 2 & 2 & N/A & 32 & $\begin{array}{l}\text { Guarana, AA, } \\
\text { Gingsen }\end{array}$ & Korea \\
\hline ED-7 & 45 & 11.3 & 11.3 & N/A & N/A & 32 & N/A & N/A & 0.608 & 8 & 2 & 2 & 2 & N/A & IS, CCL, SB, Flavor & Turkey \\
\hline ED-8 & 44 & 11.2 & 7.3 & N/A & N/A & N/A & 200 & N/A & N/A & 1.54 & 3 & N/A & 0.3 & N/A & $\begin{array}{l}\text { Color, TC, IS, CA, } \\
\text { SY }\end{array}$ & Thailand \\
\hline ED-9 & 45 & 11 & 11 & 0.35 & N/A & 32 & 400 & 40 & N/A & 10 & 2 & N/A & 2 & N/A & $\begin{array}{l}\text { GCL, IS, Flavor, } \\
\text { SA, SB }\end{array}$ & Turkey \\
\hline ED-10 & 47 & 10.9 & 10.9 & N/A & N/A & 30 & 400 & N/A & 0.6 & 8 & 2 & 2 & 0.2 & N/A & $\begin{array}{l}\text { Sugar, } \mathrm{CA}, \mathrm{CO}_{2}, \mathrm{TC} \text {, } \\
\text { Flavor }\end{array}$ & Germany \\
\hline
\end{tabular}

Note: N/A: Not available; CA: Citric acid; $\mathrm{CO}_{2}$ : Carbondioxide; GCL: Glucoronolactone; IS: Inositol; SB: Sodium benzoate; SA: Sorbic acid; SY: Sunset yellow; TC: Trisodium citrate, AA: Amino acid 


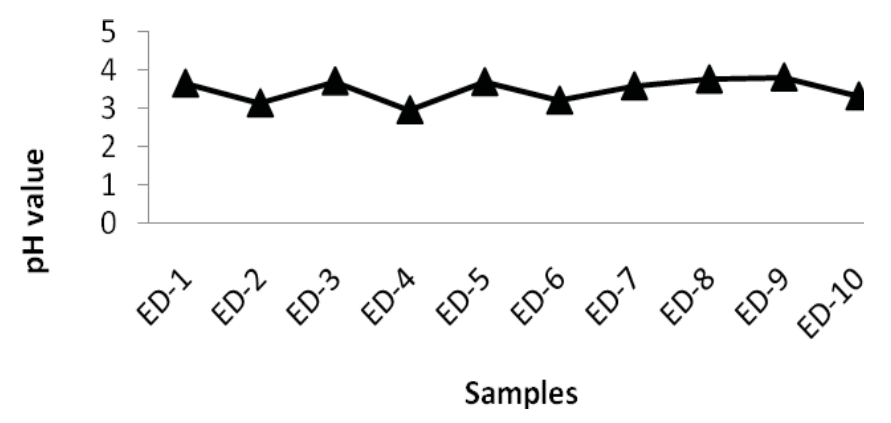

Figure 2. pH value of energy drinks

The $\mathrm{pH}$ values of different energy drinks samples is shown in Figure 2, where $\mathrm{pH}$ was found in the range of 2.96-3.81 with mean 3.48 and standard deviation 0.29. However, Humagain et al., (2013) has reported that the $\mathrm{pH}$ of energy drinks in the range of 6.5-6.7 which is quite different than our findings. For safety reason also the $\mathrm{pH}$ level of such food and beverage should be below the critical $\mathrm{pH}$ value i.e. pH 4.5 (Forsythe and Hayes, 1998). Our finding is in line with the critical $\mathrm{pH}$ value of such beverages.

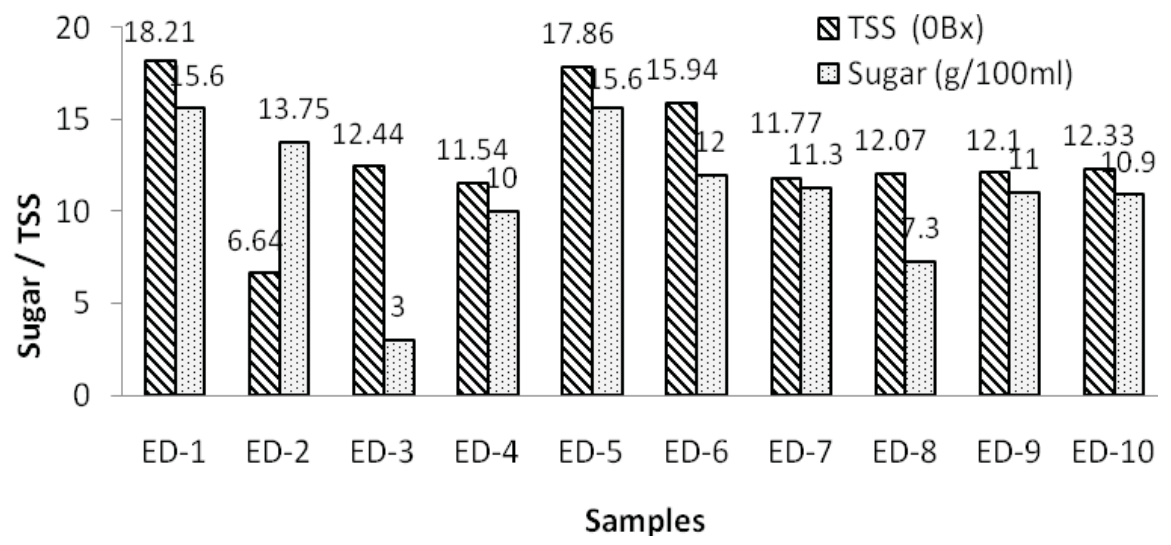

Figure 3. Comparison of TSS with label claimed for sugar content

The TSS of energy drinks was found in the range of 6.6418.21 with mean value of 13.09 and standard deviation 3.42. Figure 3 shows the comparative results of TSS versus claimed sugar value in respective sample. Besides sample ED-2, ED-3 and ED-8 other samples were found comparable in TSS and Sugar content claimed in their label. Similarly, Humagain et al., (2013) also have been reported the TSS content in energy drinks in the range of $8-16{ }^{\circ} \mathrm{Bx}$, which is quite large variation than our finding in similar types of energy drinks.

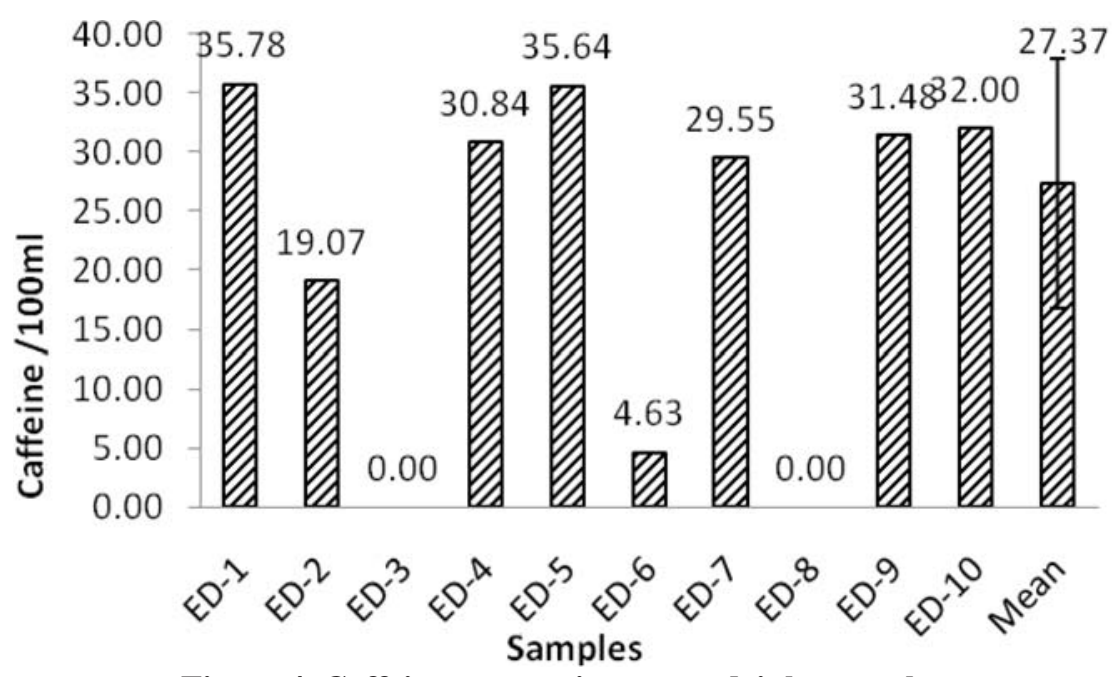

Figure 4. Caffeine content in energy drinks samples 
$\mathrm{mV}$

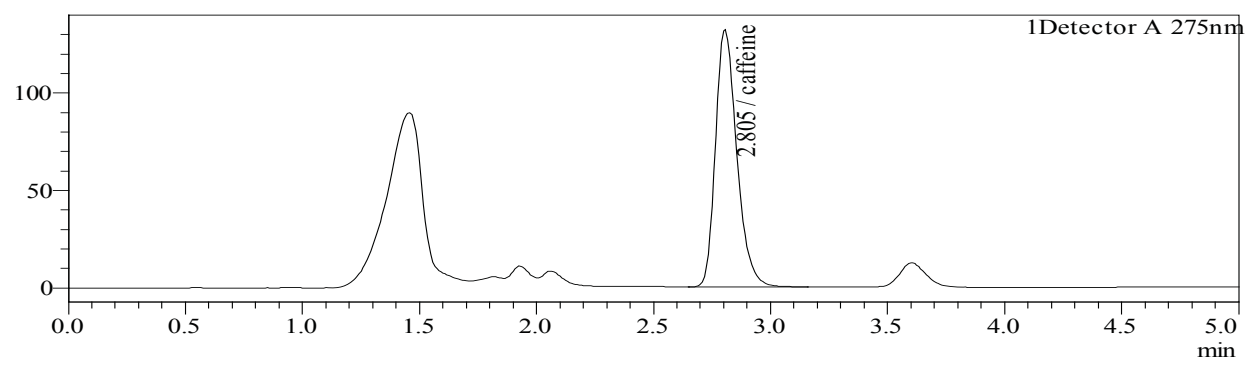

Figure 5. Chromatogram of Caffeine in sample ED-1 at 2.743 min RT

$\mathrm{mV}$

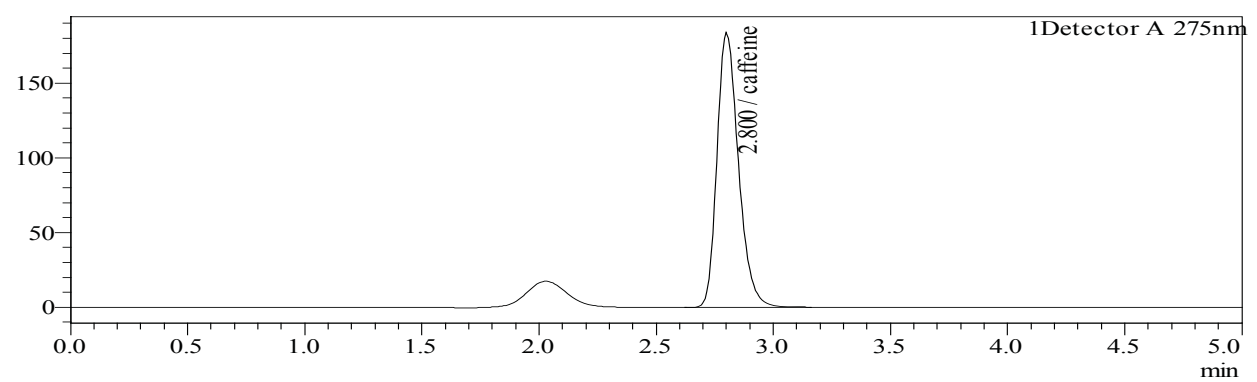

Figure 6. Chromatogram of Standard Caffeine Standard $40 \mathrm{ppm}$ at $2.743 \mathrm{~min}$ RT

Caffeine naturally occurs in plants like Coffea arabica, Coffea robusta, Thea sinensis, Theobroma cacao, Cola acuminata and Ilex paraguayensis, and it is present not only in energy drinks but a wide variety of beverages including coffee, tea, guarana, Argentine mate, carbonated soft drinks particularly in products containing cocoa or chocolates (Nawrot et al., 2003, Olmos et al., 2009). The EU regulation also requires caffeine labeling for high caffeinated drinks and foods where caffeine is added in excess of $150 \mathrm{mg} / \mathrm{L}$, must be labeled with the statement 'High caffeine content and not recommended for children or pregnant or breastfeeding women' in label (FSA, Ireland, 2015). FDA has also approved the use of caffeine in such cola type soft drinks up to $0.02 \%$ (FDA, 2003).

The Figure 3 shows that the Caffeine content is different energy drinks samples was found in the range of not detected to $35.78 \mathrm{mg} / 100 \mathrm{ml}$ with the mean value 27.37 and standard deviation 10.56. Caffeine was absent in Samples ED-3 and ED-8. The label of those samples also did not mention the caffeine content in their label. Therefore, the finding was in line with the label observation data (Table 1). However, single doses caffeine up to $200 \mathrm{mg}$ (about $3 \mathrm{mg} /$ $\mathrm{kg}$ bw for a $70 \mathrm{~kg}$ adult) do not give rise to safety concerns EFSA (2015). Likewise, Humagain et al., (2013) also reported the caffeine content in energy drinks in the range of ND to $43.03 \mathrm{mg} / 100 \mathrm{ml}$. According to ANZFA (2001), a formulated caffeinated beverage must contain no less than $14.5 \mathrm{mg} / 100 \mathrm{ml}$ and no more than $32.0 \mathrm{mg} / 100 \mathrm{ml}$ of caffeine. However, a contradictory result of caffeine content in the range of 2.1 to $217.5 \mathrm{mg} / 100 \mathrm{ml}$ for energy drinks has been reported in Portugal (Pena et al., 2005). Similarly now days there are hundreds of different brands of energy drinks marketed in USA having caffeine content ranging from a modest $50 \mathrm{mg}$ to an alarming $505 \mathrm{mg}$ per can or bottle (Reissig et al., 2009). 
Rai et al., : J. Food Sci. Technol. Nepal, Vol. 9 (66-73), 2016

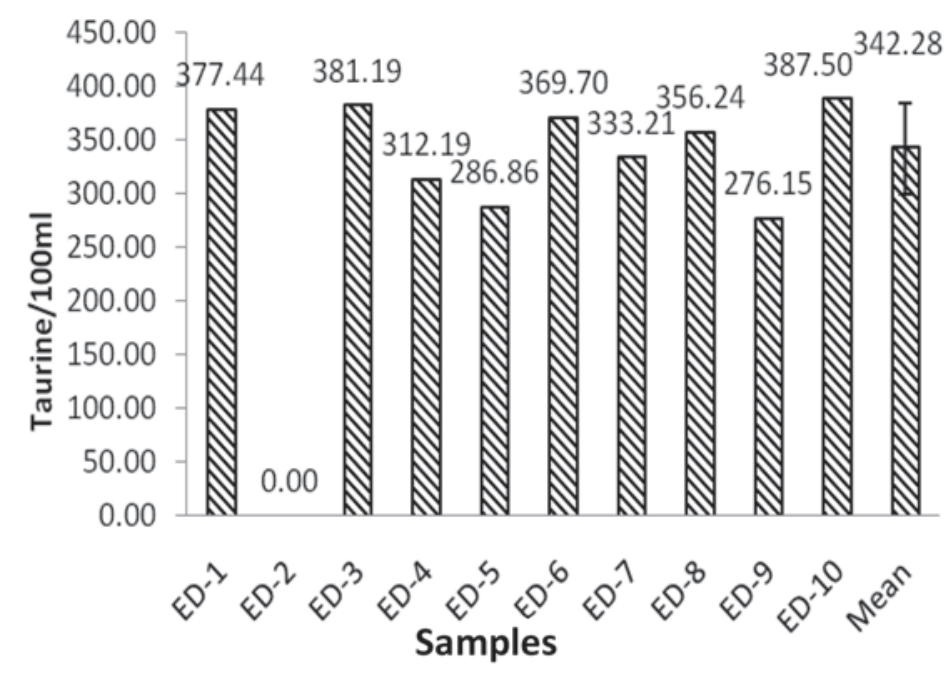

Figure 7. Taurine content in energy drink samples

$\mathrm{mV}$

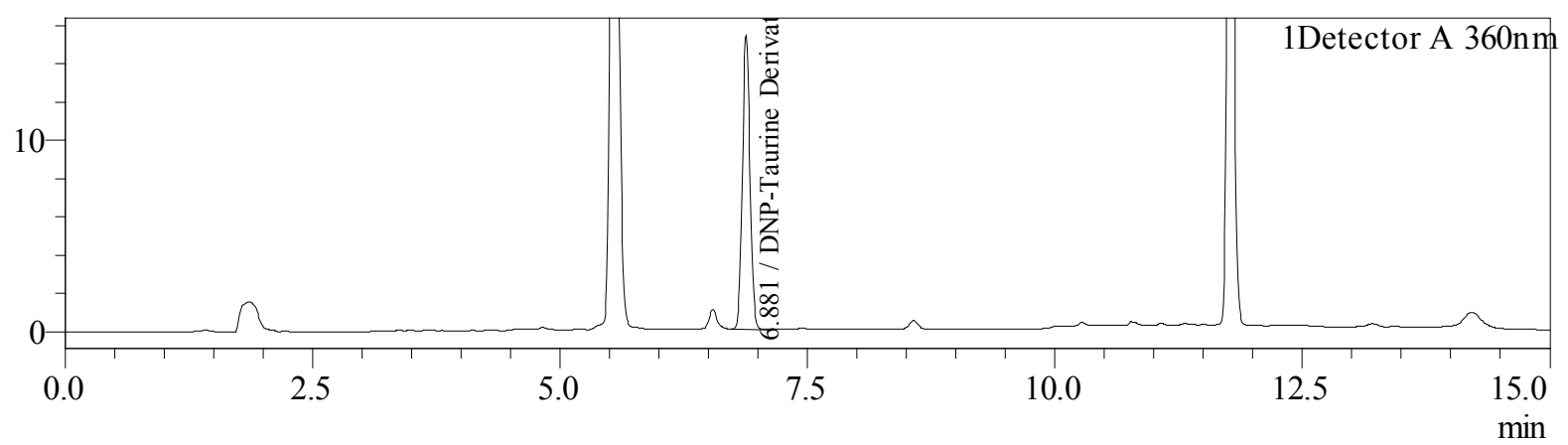

Figure 8. Chromatogram of Taurine for Sample ED-6 RT at $6.88 \mathrm{~min}$

$\mathrm{mV}$

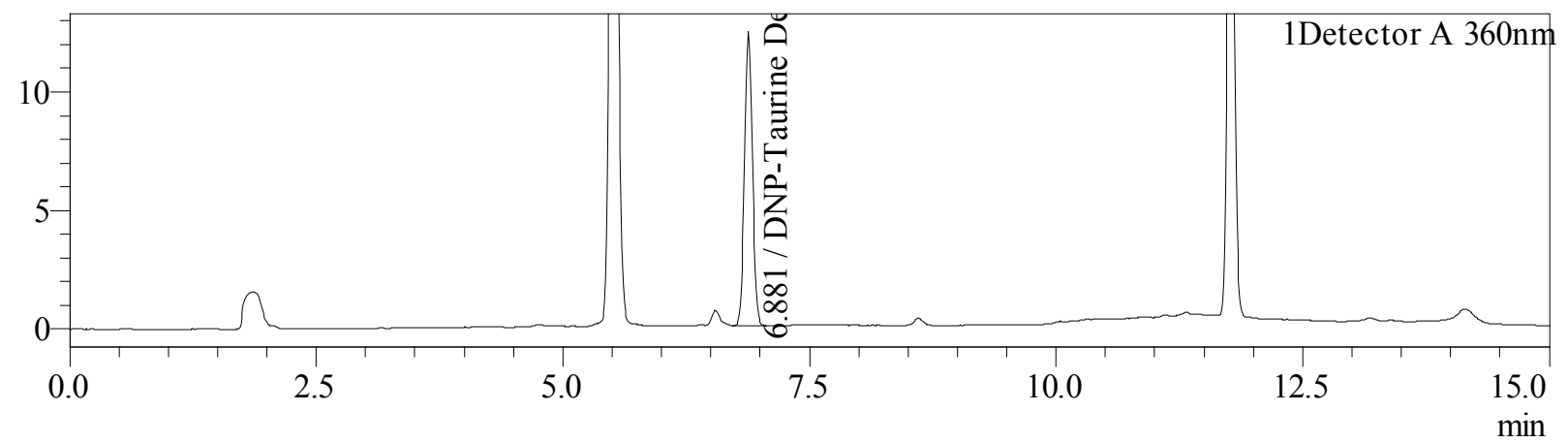

Figure 9. Chromatogram of Taurine for Standard $30 \mathrm{ppm}$ RT at $6.88 \mathrm{~min}$ 
Taurine (2-aminoethane sulphonic acid) is a semi-essential naturally occurred sulphur containing $\beta$-amino acid derived from methionine and cysteine (Stapleton et al., 1997, Wójcika et al., 2010). Naturally it has been found in several meats and sea foods, though in recent days it has become one of the major ingredients of energy drink (SCF, 1999, Wójcika et al., 2010). It has been concluded that the NOAEL of taurine is $1000 \mathrm{mg} / \mathrm{kg} \mathrm{bw} /$ day for healthy human (EFSA, 2009). Figure 6 shows the taurine content in different samples. The taurine was found in the range of not detected to $387.5 \mathrm{mg} / 100 \mathrm{ml}$ with mean value $342.28 \mathrm{mg} / 100 \mathrm{ml}$ and standard deviation 42.09. Considering the toxicological data of SCF, the ADI value of Taurine seems to be $10 \mathrm{mg} / \mathrm{kg} \mathrm{bw} /$ day, i.e. a $60 \mathrm{~kg}$ body weight person can consume $600 \mathrm{mg}$ taurine every day. Therefore, less than two can of energy drinks is enough to get the ADI level of Taurine for human.

\section{Conclusion}

From this study of energy drinks available in Nepal, majority of energy drink samples did not match the label claimed in term of Caffeine and Taurine content parameters. Therefore, the result apparently indicated that the misbranding of such beverage. However, other ingredients including vitamins and energy are yet to be confirmed.

Based on the report by Smith et al., (2000), the consumption of caffeinated energy drinks at doses of more than $250 \mathrm{mg} /$ day in adults could elucidate the adverse effect such as excitability and anxiety. Considering the result of mean caffeine content i.e. $27.37 \mathrm{mg} / 100 \mathrm{ml}$, we can suggest that a healthy adult could consume not more than two cans a day. A similar finding has also been reported by Health Canada (Godefroy, 2013).

Unlike to other developed countries such as EU, US, Canada, Australia and New-Zealand there is no any regulation for such a functional drink in Nepal. Therefore, it seems to have a regulatory mechanism for labeling, advertising and health warning for such energy drinks to sale in Nepalese markets. In other hand, excessive and haphazard intake of such energy drinks with alcohol could cause life threatening adverse effects (Avci et al., 2013). Therefore, a detail consumption survey of such drinks and Total dietary intake study is highly recommended as future scope of this study.

\section{References}

Aluqmany R., Mansoor R., Saad U., Abdullah R. and Ahamd A. (2013). Consumption of energy drinks among female secondary school students, Almadinah Almunawwarah, Kingdom of Saudi Arabia, 2011, Journal of Taibah University Medical Sciences, 8(1): 60-65.
ANZFA (2001). For recommending adoption of draft standard 2.6.4 -Formulated Caffeinated beverage in Vol. of the FOOD STANDARDS CODE, to regulate the composition and labeling of formulated caffeinated beverages.

Avci S., Sarıkaya R., Büyükcam F. (2013). Case ReportDeath of a young man after overuse of energy drink, Department of Emergency Medicine, Dışkapı Education and Research, Hospital, Ankara, Turkey, American Journal of Emergency Medicine 31 (2013) 1624.e3-1624.e4.

CAC (2001). JOINT FAO/WHO Food Standards Programme Codex Committee on Nutrition and Foods for Special Dietary Uses, Twenty-third Session Berlin, Germany, 26 30 November 2001, Discussion paper on Sports and Energy drinks, CX/NFSDU 01/11

Dikici S., Saritas A., Besir F. H. and Tasci A. H. (2013). Case Report, Do energy drinks cause epileptic seizure andischemic stroke? American Journal of Emergency Medicine, 31, 274.e1-274.e4

Duncan M. J. and Hankey J. (2013). The effect of a caffeinated energy drink on various psychological measures during submaximal cycling, Physiology \& Behavior 116$117,60-65$.

EFSA, (2013). EFSA explains risk assessment, Caffeine, DOI:10.2805/618813 ISBN 978-92-9199-677-3

EFSA (2014). Scientific Opinion on the substantiation of a health claim related to caffeine and increased alertness pursuant to Article 13(5) of Regulation (EC) No 1924/20061 , EFSA Panel on Dietetic Products, Nutrition and Allergies (NDA)2, 3, European Food Safety Authority (EFSA), Parma, Italy, EFSA Journal 2014;12(2):3574

EFSA (2015). Scientific Opinion on the safety of caffeine1 EFSA Panel on Dietetic Products, Nutrition and Allergies (NDA)2,3 European Food Safety Authority (EFSA), Parma, Italy, EFSA Journal 2015;13(5):4102

Food and Drug Administration, (2003). Substances generally recognized as safe. Code of Federal Regulations. Title 21 volume 3, Sec. 182.1180. http://www.cfsan.fda. gov/lrd/fcf182.html. Accessed on February 28, 2008.

Forsythe, S.J. and Hayes P.R. (1998). Food Hygiene and Safety Legislation in the UK. In: Food Hygiene Microbiology and HACCP, third edition, An Aspen Publication, ISBN 978-14615-2193-8 (e-book).

FSA, Ireland (2015). High caffeine energy drinks and other foods containing caffeine - In: https:/www.food.gov.uk/ science/additives/ energydrinks\#sthash. 9e 8c ytML.dpuf 
Godefroy, S. (2013). Caffeinated Energy Drinks -Health Risk Assessment and Current Risk Management Approach, Paper presentation, Food Directorate, Health Canada, Fredericton, New Brunswick.

Humagain B., Baniya J. and Lamsal K. P. (2013). Initiation for the formulation of policy to regulate the unnecessary use of energy drinks, Technical Report, WHO, Country Office for Nepal, prepared by Forum for Protection of Consumer Rights-Nepal, Newbaneswar, Kathmandu.

Johnson, C.K., 2006. Caffeine-Stoked energy drinks worry docs. The Washington Post, October 29. In: http://www. washingtonpost.com/wpdyn/content/article/2006/10/29/ AR2006102900290.html.

McConn B. (2012). Determination of taurine in energy drinks by high-performance liquid chromatography. Concordia College Journal of Analytical Chemistry, 3, 4752.

Nawrota P. , Jordan S., Eastwood J., Rotstein J., Hugenholtz A. and Feeley M. (2003). Effects of caffeine on human health Food Additives and Contaminants, Vol. 20, No. 1, $1-30$

Olmos V., Bardoni N., Ridolfi A.S. and Villaamil Lepori E.C. (2009). Caffeine levels in beverages from Argentina's market: application to caffeine dietary intake assessment, Food Additives and Contaminants, Vol. 26, No. 3:275-281.

Pena A, Lino C. and Silveira M. I. N. (2005). Survey of caffeine levels in retail beverages in Portugal, Food Additives and Contaminants, February 2005; 22(2): 91-96.

Reissig C. J., Strain E. C. and Griffiths R. R. (2009). Caffeinated energy drinks - A growing problem, Drug and Alcohol Dependence, vol. (99) 1-10.

Rotstein J., Barber J., Strowbridge C., Hayward S., Rong H. and Godefroy S. B. (2013). Energy Drinks: An Assessment of the Potential Health Risks in the Canadian Context, International Food Risk Analysis Journal DOI: $10.5772 / 56723$

SCF (Scientific Committee on Food), 1999. Opinion on caffeine, taurine and D-glucurono- $\gamma$ - lactone as constituents of so-called "energy" drinks, adopted on 21 January 1999. Minutes of the 115th Meeting of the Scientific Committee on Food held on 20-21st January 1999. European Commission DG Consumer Policy and Consumer Health Protection. Document XXIV/2146/99.
Smith P. F., Smith A., Miners J., McNeil J. and Proudfoot A. (2000). Report from the expert working group on the safety aspects of dietary caffeine, Australia New Zealand Food Authority.

Stapleton P. P., Charles R. P., Redmond H. P. and BouchierHayes D. J. (1997).Taurine and human nutrition, Clinical Nutrition, 16:103-108.

Saritas A, Dikici S., Gunes H. (2014). Adverse effects of energy drinks, Am J EmergMed (2014), http://dx.doi. org/10.1016/j.ajem.2014.11.054

The EFSA Journal (2009). Scientific opinion, The use of taurine and D-glucurono- $\gamma$-lactone as constituents of the socalled “energy” drinks, EFSA Journal, 935, 2-31.

Usman A and Jawaid A. (2012). Hypertension in a young boy: an energy drink effect. BMC Res Notes;5:591.

Wójcika O. P., Koeniga K. L., Zeleniuch-Jacquottea, A., Costa M. and Chena Y., (2010). The potential protective effects of taurine on coronary heart disease, Atherosclerosis 208 19-25. 